\title{
Phytochemical Composition, Antioxidant Activity, and Enzyme Inhibitory Activities ( $\alpha$-Glucosidase, Xanthine Oxidase, and Acetylcholinesterase) of Musella lasiocarpa
}

\author{
Rurui $\mathrm{Li}^{1,2}$, Yuerong $\mathrm{Ru}^{2}$, Zhenxing Wang ${ }^{1,2}{ }^{\mathbb{D}}$, Xiahong $\mathrm{He}^{3, *}$, Kin-Weng Kong ${ }^{4}{ }^{\oplus}$, Tingting Zheng ${ }^{5}$ \\ and Xuechun Zhang ${ }^{1,2, *}$
}

Citation: Li, R.; Ru, Y.; Wang, Z.; He, X.; Kong, K.-W.; Zheng, T.; Zhang, X. Phytochemical Composition, Antioxidant Activity, and Enzyme Inhibitory Activities ( $\alpha$-Glucosidase, Xanthine Oxidase, and Acetylcholinesterase) of Musella lasiocarpa. Molecules 2021, 26, 4472. https://doi.org/10.3390/ molecules26154472

Academic Editor: Maria Emília de Sousa

Received: 24 June 2021

Accepted: 21 July 2021

Published: 24 July 2021

Publisher's Note: MDPI stays neutral with regard to jurisdictional claims in published maps and institutional affiliations.

Copyright: (c) 2021 by the authors Licensee MDPI, Basel, Switzerland. This article is an open access article distributed under the terms and conditions of the Creative Commons Attribution (CC BY) license (https:/ / creativecommons.org/licenses/by/ $4.0 /)$
1 Key Laboratory for Forest Resources Conservation and Utilization in the Southwest Mountains of China, Ministry of Education, Southwest Forestry University, Kunming 650224, China; lirurui2021@163.com (R.L.); wangzhenxingfood@163.com (Z.W.)

2 College of Life Science, Southwest Forestry University, Kunming 650224, China; ruyue13732704447@163.com

3 College of Horticulture and Landscape, Southwest Forestry University, Kunming 650224, China

4 Department of Molecular Medicine, Faculty of Medicine, University of Malaya,

Kuala Lumpur 50603, Malaysia; kongkm@um.edu.my

5 Key Laboratory of Leather Chemistry and Engineering, Ministry of Education, Sichuan University, Chengdu 610065, China; zhengtingtings@163.com

* Correspondence: hexiahong@googlemail.com (X.H.); zhangxuechun@swfu.edu.cn (X.Z.)

Abstract: In this study, we aimed to investigate the chemical components and biological activities of Musella lasiocarpa, a special flower that is edible and has functional properties. The crude methanol extract and its four fractions (petroleum ether, ethyl acetate, n-butanol, and aqueous fractions) were tested for their total antioxidant capacity, followed by their $\alpha$-glucosidase, acetylcholinesterase, and xanthine oxidase inhibitory activities. Among the samples, the highest total phenolic and total flavonoid contents were found in the ethyl acetate (EtOAc) fraction (224.99 mg GAE/g DE) and crude methanol extract (187.81 mg QE/g DE), respectively. The EtOAc fraction of Musella lasiocarpa exhibited the strongest DPPH. scavenging ability, ABTS. ${ }^{+}$scavenging ability, and $\alpha$-glucosidase inhibitory activity with the $\mathrm{IC}_{50}$ values of $22.17,12.10$, and $125.66 \mu \mathrm{g} / \mathrm{mL}$, respectively. The EtOAc fraction also showed the strongest ferric reducing antioxidant power (1513.89 $\mathrm{mg} \mathrm{FeSO}_{4} / \mathrm{g} \mathrm{DE}$ ) and oxygen radical absorbance capacity ability (524.11 mg Trolox/g DE), which were higher than those of the control BHT. In contrast, the aqueous fraction demonstrated the highest acetylcholinesterase inhibitory activity $\left(\mathrm{IC}_{50}=10.11 \mu \mathrm{g} / \mathrm{mL}\right)$, and the best xanthine oxidase inhibitory ability $\left(\mathrm{IC}_{50}=5.23 \mu \mathrm{g} / \mathrm{mL}\right)$ was observed from the crude methanol extract as compared with allopurinol $(24.85 \mu \mathrm{g} / \mathrm{mL})$. The HPLCMS/MS and GC-MS analyses further revealed an impressive arsenal of compounds, including phenolic acids, fatty acids, esters, terpenoids, and flavonoids, in the most biologically active EtOAc fraction. Taken together, this is the first report indicating the potential of Musella lasiocarpa as an excellent natural source of antioxidants with possible therapeutic, nutraceutical, and functional food applications.

Keywords: Musella lasiocarpa; antioxidant activity; $\alpha$-glucosidase; xanthine oxidase; acetylcholinesterase; HPLC-MS/MS; GC-MS

\section{Introduction}

Musella lasiocarpa (Franch.) belongs to the monotypic genus Musella in the family Musaceae that is found primarily in southwestern China. It has attracted increasing attention around the world for its lotus-like golden inflorescence with more than eight-month anthesis [1-3]. M. lasiocarpa is traditionally used as medicine, food, and fodder [4]. It is a rich source of nutrients, and its comprehensive nutritional value and application in swine diets were reported in an earlier study [5]. Apart from that, it also has very high ecological utilization, horticultural, and conservation values. After a long period of exploration and 
development, $M$. lasiocarpa has been successfully developed as a semi-cultivated plant from a wild plant.

The inflorescence is the most important characteristic and function organ of M. lasiocarpa. In addition to being a popular potted plant, landscaping plant, and cut flower, its flower has also been used as an antiphlogistic, hemostatic, anti-enteritis, anti-constipation, detoxification, and anti-gynecological disease agent as well as to alleviate drunkenness $[6,7]$. Despite the numerous health benefits, there has been little research concerning $M$. lasiocarpa due to its distribution in a small geographical region in China.

With the development of its artificial cultivation and introduction all over the world, more researchers have begun to focus on its biological and pharmacological activities. In the last two decades, novel compounds have been isolated from the M. lasiocarpa flower, which showed significant in vitro anticancer activities and some degree of antimicrobial activity $[4,7,8]$. These results illustrate the potential of the $M$. lasiocarpa flower as a source of novel drugs, nutraceuticals, and functional foods. However, until now, relatively little was known about its chemical composition and biological activity, which significantly restrained its applications.

Oxidative stress, which is mainly due to the excessive production of reactive oxygen species (ROS), could induce a wide range of chronic disorders, including diabetes, Alzheimer's disease, cancer, obesity, atherosclerosis, cardiovascular diseases, and inflammatory disorders [9]. Diabetes mellitus is a metabolic disorder caused by hyperglycemia, affecting nearly $10 \%$ of the world population, while Alzheimer's disease (AD) is an irreversible disease caused by severe progressive neurological decline, and its incidence increases with age [10]. Natural antioxidants have exhibited strong functions against oxidative stress, and they possess a wide range of pharmacological activities [11,12]. Hence, natural antioxidants could be an effective preventive agent for oxidative stress-related disorders, such as diabetes and neurodegenerative diseases [13].

To the best of our knowledge, only a few chemical constituents of $M$. lasiocarpa have been reported, and the correlation between these phytochemical components and their biological activities has not been elucidated. Therefore, this is the first study where $M$. lasiocarpa flower was extracted and fractionated by solvents of different polarities, then a comprehensive analysis of the chemical compositions and biological activities of these fractions was performed, including the total phenolic and total flavonoid contents, antioxidant activity, $\alpha$-glucosidase, acetylcholinesterase, and xanthine oxidase inhibitory abilities, in order to assess the potential in preventing oxidative stress-related diseases. In addition, the phytochemical composition of the most active fraction was determined using HPLC-MS/MS and GC-MS to explore the chemical-activity relationship.

\section{Results}

\subsection{Total Phenolic and Flavonoid Contents}

Table 1 shows that there was a significant difference in the total phenolic content (TPC) and total flavonoid content (TFC) between different fractions. For TPC, this decreased in the order of ethyl acetate fraction (EtOAc), crude methanol extract (CME), aqueous fraction $(\mathrm{AF}), \mathrm{n}$-Butanol fraction $(\mathrm{n}-\mathrm{BuOH})$, and petroleum ether fraction (PE), and the values were $224.99 \pm 6.99,129.4 \pm 2.95,111.59 \pm 2.5,64.61 \pm 1.49$, and $12.67 \pm 3.15(\mathrm{mg} \mathrm{QE} / \mathrm{g}$ DE). TFC decreased in descending order: CME (187.81 \pm 9.74 (mg GAE/g DE)), EtOAc $(178.95 \pm 13.04 \mathrm{mg} \mathrm{GAE} / \mathrm{g}$ DE), AF (18.85 $\pm 1.31 \mathrm{mg} \mathrm{GAE} / \mathrm{g} \mathrm{DE}), \mathrm{n}-\mathrm{BuOH}(13.04 \pm 0.31 \mathrm{mg}$ $\mathrm{GAE} / \mathrm{g} \mathrm{DE})$, and PE (0.54 $\pm 0.03 \mathrm{mg} \mathrm{GAE} / \mathrm{g})$. Among the fractions, EtOAc exhibited the highest TPC and TFC values, whereas the TPC and TFC of PE were the lowest, which is consistent with the results reported previously [14]. 
Table 1. The TPC and TFC values of M. lasiocarp extracts.

\begin{tabular}{ccc}
\hline Samples & TPC & TFC \\
\hline CME & $129.40 \pm 2.95^{\mathrm{b}}$ & $187.81 \pm 9.74^{\mathrm{a}}$ \\
PE & $12.67 \pm 3.15^{\mathrm{e}}$ & $0.54 \pm 0.03^{\mathrm{c}}$ \\
EtOAc & $224.99 \pm 6.99^{\mathrm{a}}$ & $178.95 \pm 13.04^{\mathrm{a}}$ \\
$\mathrm{n}-\mathrm{BuOH}$ & $64.61 \pm 1.49^{\mathrm{d}}$ & $13.04 \pm 0.31^{\mathrm{bc}}$ \\
AF & $111.59 \pm 2.50^{\mathrm{c}}$ & $18.85 \pm 1.31^{\mathrm{b}}$ \\
\hline
\end{tabular}

$\mathrm{TPC}=$ total phenolic content (mg GAE/g DE); TFC = total flavonoid content (mg QE/g DE); CME = crude methanol extract; PE = petroleum ether fraction; $\mathrm{EtOAc}=$ ethyl acetate fraction; $\mathrm{n}-\mathrm{BuOH}=\mathrm{n}-\mathrm{Butanol}$ fraction; and $\mathrm{AF}=$ aqueous fraction. The means with different lowercase letters in the same column are significantly different $(p<0.05)$.

\subsection{Antioxidant Activity}

\subsubsection{DPPH Radical Scavenging Activity}

The DPPH. is a stable nitrogen-centered free radical, which serves as the reaction indicator molecule and is widely used in the evaluation of antioxidant activity [15]. The results are shown in Figure 1A, and significant differences between the extract and the fractions produced with different solvents were observed. Among them, EtOAc showed the strongest DPPH radical scavenging activity with $\mathrm{IC}_{50}$ values of $22.17 \pm 6.01 \mu \mathrm{g} / \mathrm{mL}$, which had no statistically significant difference when compared with the control $\mathrm{Vc}_{\mathrm{c}}$ and $\mathrm{BHT}$. This was followed by $\mathrm{CME}, \mathrm{n}-\mathrm{BuOH}, \mathrm{PE}$, and $\mathrm{AF}$, with $\mathrm{IC}_{50}$ values ranging from $48.21 \pm 7.82$ to $435.86 \pm 17.81 \mu \mathrm{g} / \mathrm{mL}$.
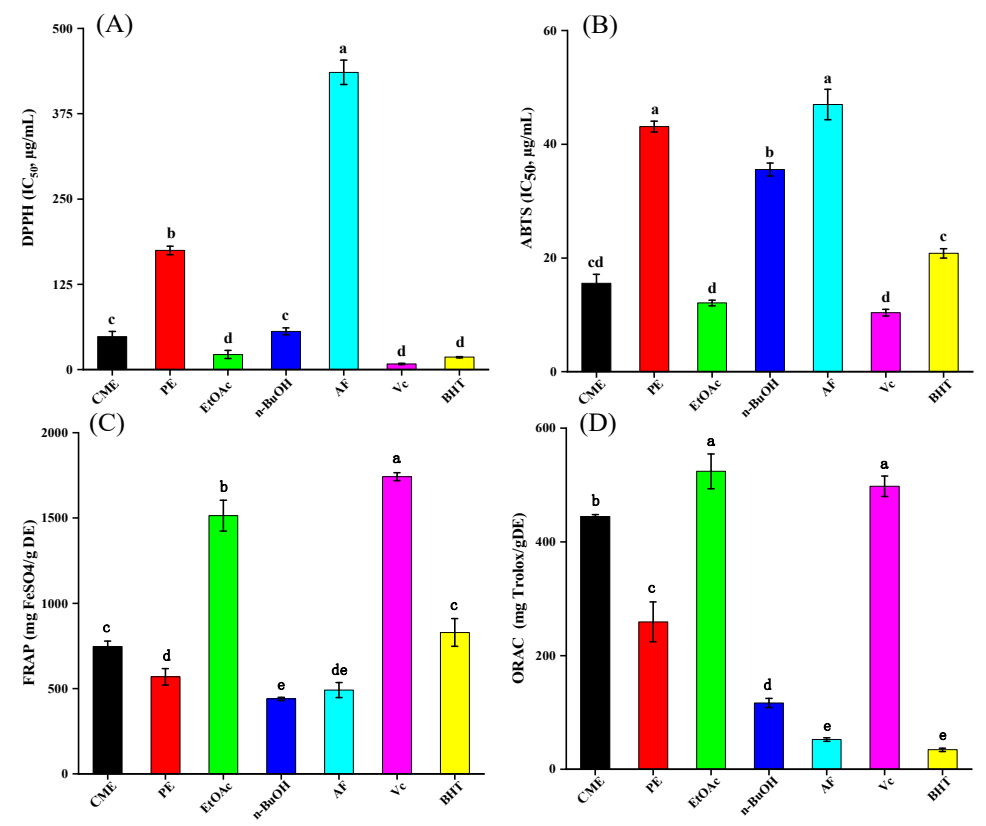

Figure 1. The antioxidant activity of samples or controls. (A) DPPH. scavenging activity (DPPH). (B) ABTS. ${ }^{+}$scavenging ability (ABTS). (C) Ferric reducing antioxidant power (FRAP). (D) Oxygen radical absorbance capacity $(\mathrm{ORAC}) . \mathrm{CME}=$ crude methanol extract; $\mathrm{PE}=$ petroleum ether fraction; $\mathrm{EtOAc}=$ ethyl acetate fraction; $\mathrm{n}-\mathrm{BuOH}=\mathrm{n}-\mathrm{Butanol}$ fraction; and $\mathrm{AF}=$ aqueous fraction. The columns with different lowercase letters represent a significant difference at $p<0.05$.

Correlation analyses (Figure 2) revealed that the significant negative correlation $(r=-0.67, p<0.01)$ association was found between the DPPH. scavenging activity with TPC, which was even higher than the correlation with TFC $(r=-0.57, p<0.05)$. As DPPH is expressed by $\mathrm{IC}_{50}$ value, the lower negative correlation value between DPPH and TPC indicating a stronger DPPH radical scavenging at higher TPC. 


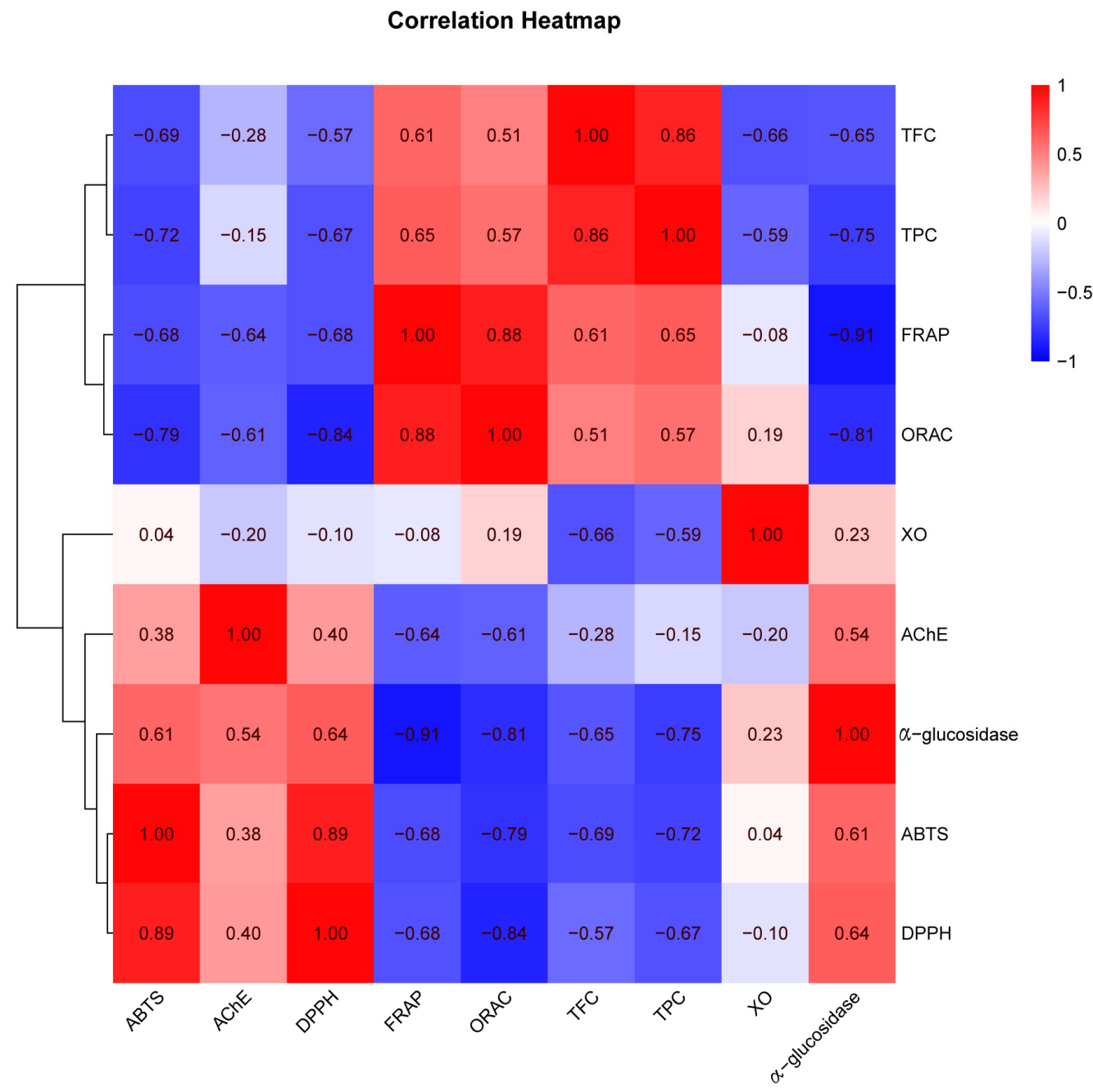

Figure 2. Heatmap graph of correlation analysis. $p$-value (ranging from -1 to 1 ) and corresponding color (red to blue) represent the magnitude of the Pearson correlation coefficient $(r)$ in the heatmap; TPC $=$ total phenolic content; TFC $=$ total flavonoid content; DPPH $=$ DPPH scavenging activity; ABTS $=$ ABTS ${ }^{+}$scavenging ability; FRAP $=$ferric reducing antioxidant power; ORAC $=$ oxygen radical absorbance capacity; $\alpha$-glucosidase $=$ the $\mathrm{IC}_{50}$ value for $\alpha$-glucosidase inhibitory activity; $\mathrm{AChE}=$ the $\mathrm{IC}_{50}$ value for acetylcholinesterase inhibitory activity; and $\mathrm{XO}=$ the $\mathrm{IC}_{50}$ value for xanthine oxidase inhibitory activity. The different letters represent a significant difference, $p<0.05$.

This implies that the DPPH radical scavenging activity of $M$. lasiocarpa may be mainly contributed from phenolics. The results from the principal component analysis (PCA) are shown in Figure 3A, which reveal that the triplicate replicates of different extracts and fractions were well separated. All of the nine indicators were well differentiated by principal coordinates analysis ( $\mathrm{PCoA}$ ) in Figure $3 \mathrm{~B}$, and the $\mathrm{DPPH}$ - scavenging activity had almost identical principal component coordinates to the $\alpha$-glucosidase inhibitory activity. Additionally, the other three antioxidant activities had relatively close distances to TPC and TFC. 
(A)

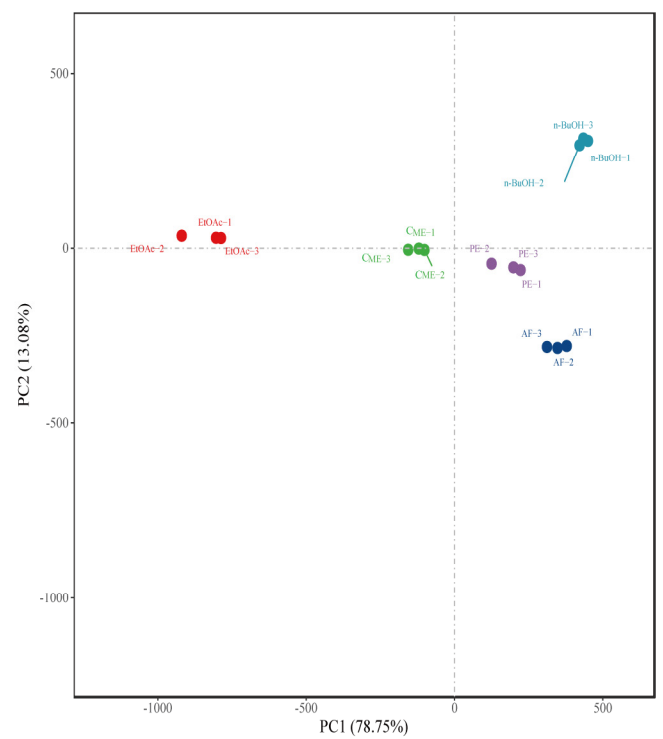

(B)

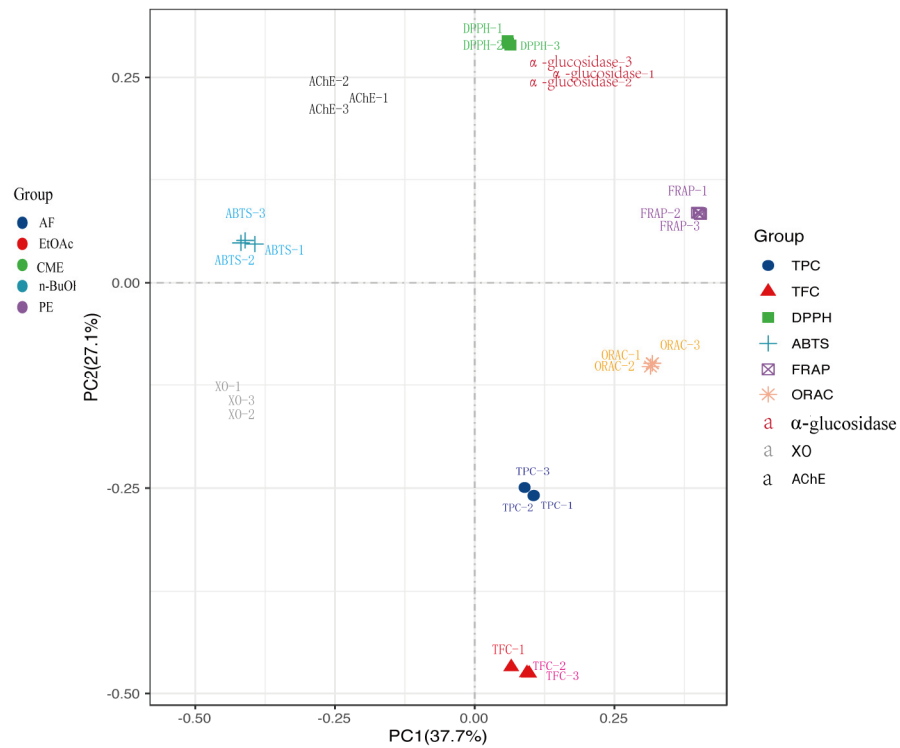

Figure 3. Principal component analysis (PCA) of different samples and indicators. (A) PCA of five M. lasiocarpa extract and fractions. (B) principal co-ordinates analysis (PCoA) of nine indicators of active ingredient content and biological activity. $\mathrm{CME}=$ crude methanol extract; $\mathrm{PE}=$ petroleum ether fraction; EtOAc = ethyl acetate fraction; $\mathrm{n}-\mathrm{BuOH}=\mathrm{n}-\mathrm{Butanol}$ fraction; $\mathrm{AF}=$ aqueous fraction; $\mathrm{TPC}=$ total phenolic content; $\mathrm{TFC}=$ total flavonoid content; $\mathrm{DPPH}=\mathrm{DPPH}$. scavenging activity; ABTS = ABTS. ${ }^{+}$scavenging ability; FRAP $=$ferric reducing antioxidant power; ORAC $=$oxygen radical absorbance capacity; $\alpha$-Glucosidase $=$ the $\mathrm{IC}_{50}$ value for $\alpha$-glucosidase inhibitory activity; $\mathrm{AChE}=$ the $\mathrm{IC}_{50}$ value for acetylcholinesterase inhibitory activity; and $\mathrm{XO}=$ the $\mathrm{IC}_{50}$ value for xanthine oxidase inhibitory activity.

\subsubsection{ABTS Radical Scavenging Activity}

The ABTS. ${ }^{+}$scavenging capacity is based on the ability of hydrogen donating antioxidants to scavenge the long-life radical cation $\mathrm{ABTS}^{+}$by either electron donation or hydrogen electron transfer [16]. As shown in Figure 1B, the EtOAc fraction exhibited the highest scavenging capacity with an $\mathrm{IC}_{50}$ value of $12.10 \pm 0.48 \mu \mathrm{g} / \mathrm{mL}$, which was comparable to that of the positive control Vc $(10.38 \pm 0.57 \mu \mathrm{g} / \mathrm{mL})$ and significantly stronger than another control, BHT $(20.81 \pm 0.81 \mu \mathrm{g} / \mathrm{mL})$. This was followed by CME, where the $\mathrm{IC}_{50}$ value was $15.55 \pm 1.56 \mu \mathrm{g} / \mathrm{mL}$, which was also significantly stronger than BHT. This was then followed by AF $(46.99 \pm 6.86 \mu \mathrm{g} / \mathrm{mL}), \operatorname{PE}(43.12 \pm 0.96 \mu \mathrm{g} / \mathrm{mL})$, and $\mathrm{n}-\mathrm{BuOH}(35.56 \pm 1.12 \mu \mathrm{g} / \mathrm{mL})$.

It is generally believed that the total phenols, and particularly the total flavonoids, are the main contributors to the scavenging activity estimated by the DPPH and ABTS assays [17], and this was also confirmed by the result of the correlation analysis (Figure 2). A significant correlation $(r=0.89, p<0.01)$ was found between the DPPH and ABTS radical scavenging capacity, which was because the DPPH and ABTS assays had a similar reaction mechanism based on the transfer of a single electron.

\subsubsection{Ferric Reducing Antioxidant Power}

The ferric reducing antioxidant power (FRAP) assay has demonstrated the ability of antioxidants to reduce iron (III) to iron (II) in a redox-linked colorimetric reaction that involves a single electron transfer [18] and is widely used to screen high-antioxidant ability substances. Based on the standard curve of $\mathrm{FeSO}_{4}\left(\mathrm{y}=0.0109 \mathrm{x}-0.0968, R^{2}=0.9968\right)$, the FRAP results of the samples were calculated and are shown in Figure 1C.

Among all the extract and fractions, EtOAc also exhibited the strongest FRAP (1513.89 \pm 90.33 $\mathrm{mg} \mathrm{FeSO} / \mathrm{g} \mathrm{DE}$ ), which was significantly higher than the other fractions (from $439.49 \pm 8.54$ to $\left.1513.89 \pm 90.33 \mathrm{mg} \mathrm{FeSO}_{4} / \mathrm{g} \mathrm{DE}\right)$. Although lower than the positive control Vc (1741.74 \pm 
$\left.23.19 \mathrm{mg} \mathrm{FeSO}_{4} / \mathrm{g} \mathrm{DE}\right)$, it was nearly double that of another positive control BHT (828.79 \pm $81.46 \mathrm{mg} \mathrm{FeSO}_{4} / \mathrm{g} \mathrm{DE}$ ). From Figure 2, FRAP demonstrated a good and significant correlation at $p<0.05$ with TPC and TFC, and the correlation coefficients were 0.65 and 0.61 , respectively. In addition, the correlations between FRAP and DPPH/ABTS $(-0.68, p<0.01)$ were significantly lower than the DPPH-ABTS correlation $(0.89, p<0.01)$, which was due to differences in their antioxidant mechanism.

\subsubsection{Oxygen Radical Absorbance Capacity}

The oxygen radical absorbance capacity (ORAC) is a classical in vitro antioxidant assay that measured the radical chain-breaking antioxidant activity, and the mechanism is based on hydrogen atom transfer [19]. According to the Trolox standard curve $(y=1.2372 x+$ $\left.12.774, R^{2}=0.9984\right)$, the values of ORAC were obtained and are shown in Figure 1D. EtOAc presented a superior ORAC value of $524.11 \pm 30.54 \mathrm{mg} \mathrm{TE} / \mathrm{g}$ DE, which was even higher than $\mathrm{Vc}_{\mathrm{c}}(497.85 \pm 18.01 \mathrm{mg} \mathrm{TE} / \mathrm{g} \mathrm{DE})$. This was followed by PE, n-BuOH, and AF, with the values of $259.37 \pm 35.05,116.84 \pm 116.84$, and $52.41 \pm 3.05 \mathrm{mg}$ TE/g DE, respectively.

A relative association $(r=0.57, p<0.05)$ was seen between ORAC and TFC, which revealed that polyphenols were the main active compounds for ORAC. In contrast, ORAC displayed extremely high negative correlations with the DPPH and ABTS radical scavenging capacity $(r=-0.79$ to $-0.84, p<0.01)$, and FRAP $(r=0.88, p<0.01)$. This is because the ORAC assay represents the sum of the most abundant antioxidants available and is more sensitive, effective, and relevant to human biology when compared with the FRAP, DPPH., and ABTS. ${ }^{+}$scavenging assays $[16,20]$.

\section{3. $\alpha$-Glucosidase Inhibitory Ability}

In clinical applications, $\alpha$-glucosidase inhibitors are effective in reducing postprandial hyperglycemia by delaying the digestion of carbohydrates and, hence, reducing the absorption of sugars, and they have been recognized as efficient agents in the treatment of type 2 diabetes by virtue of being safe and economical with small side effects [21-23].

From Figure $4 \mathrm{a}$, all the extracts and fractions of $M$. lasiocarpa significantly inhibited $\alpha$-glucosidase in a dose-dependent manner. At the same concentration, EtOAc gave the highest inhibition percentage, followed by $\mathrm{CME}, \mathrm{AF}, \mathrm{PE}$, and n-BuOH . Their calculated $\mathrm{IC}_{50}$ values were also shown in Figure $4 \mathrm{~b}$ with the values of $18.86 \pm 0.44,79.15 \pm 6.03$, $143.02 \pm 7.66$, and $574.86 \pm 16.45 \mu \mathrm{g} / \mathrm{mL}$, respectively. Surprisingly, the $\alpha$-glucosidase inhibitory activity of EtOAc and CME was significantly stronger than that of the positive control/drug acarbose $(125.66 \pm 6.13 \mu \mathrm{g} / \mathrm{mL})$.

This illustrates the therapeutic potential of $M$. lasiocarpa as a natural antidiabetic agent. Correlation analyses revealed that polyphenols were a major contributing factor for the $\alpha$-glucosidase inhibitory activity of $M$. lasiocarpa $(r=-0.75, p<0.01)$. Additionally, a good relationship of $\alpha$-glucosidase inhibitory activity with both ORAC and FRAP was observed $(r=-0.81$ to $-0.91, p<0.01)$. 

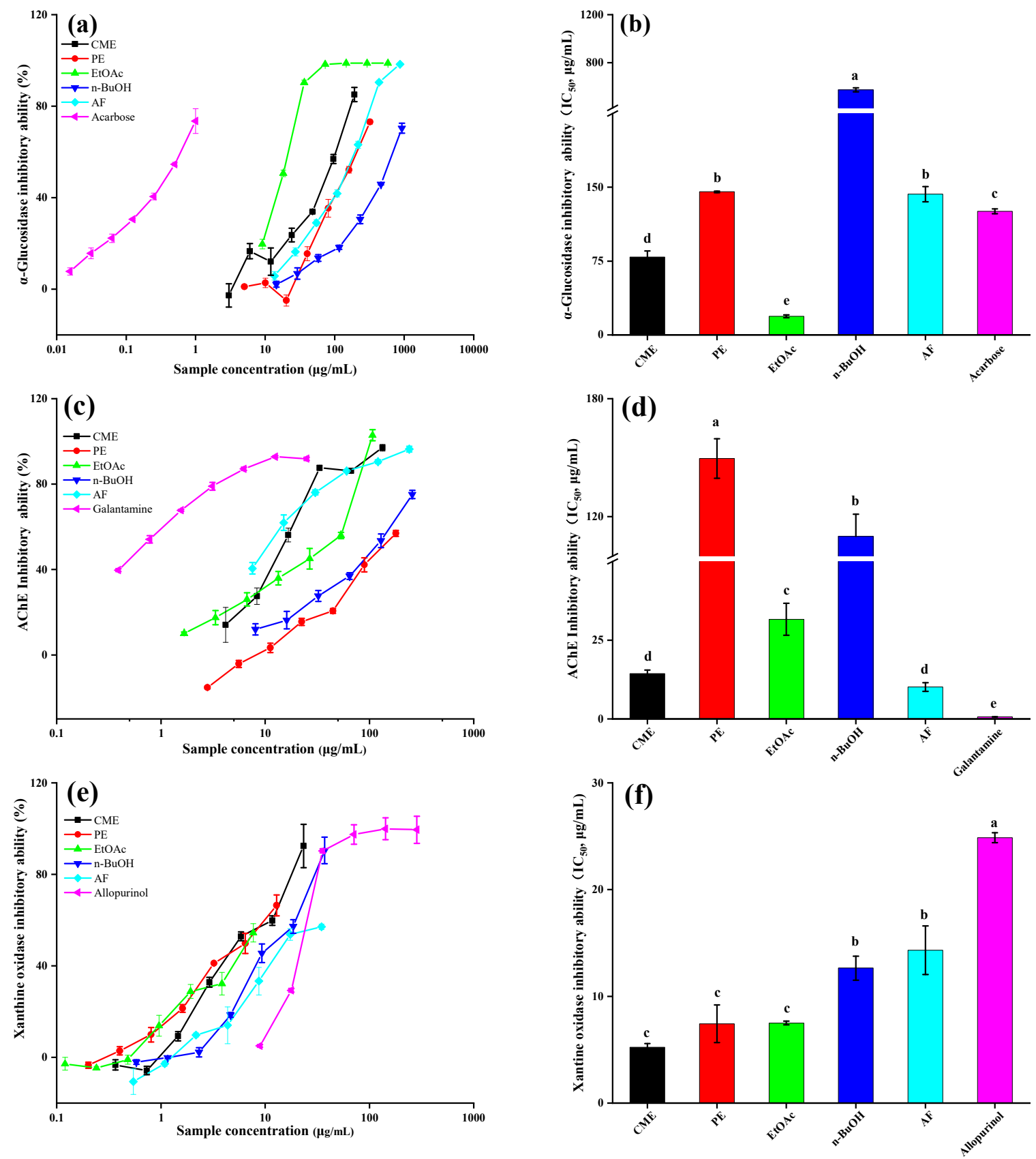

Figure 4. The enzyme inhibitory ability of the M. lasiocarpa. (a) The inhibition rate of the $\alpha$-glucosidase with different concentrations. (b) The $\mathrm{IC}_{50}$ values of different samples toward $\alpha$-glucosidase inhibitory activity. (c) The inhibition rate of the XO with different concentrations. (d) The $\mathrm{IC}_{50}$ values of different samples toward XO inhibitory activity. (e) The inhibition rate of the AChE with different concentrations. (f) The $\mathrm{IC}_{50}$ values of different samples toward AChE inhibitory activity. $\mathrm{CME}=$ crude methanol extract; $\mathrm{PE}=$ petroleum ether fraction; $\mathrm{EtOAc}=$ ethyl acetate fraction; $\mathrm{n}-\mathrm{BuOH}=\mathrm{n}-\mathrm{Butanol}$ fraction; and $\mathrm{AF}=$ aqueous fraction. $\mathrm{IC}_{50}=$ half maximal inhibitory concentration. Columns with different letters indicate a significant difference $(p<0.05)$.

\subsection{Acetylcholinesterase Inhibitory Ability}

According to the theory of the "cholinergic hypothesis", acetylcholinesterase (AChE) inhibitors could increase cholinergic activity by preserving the levels of acetylcholine and further improve the symptoms of AD [24]. Therefore, $\mathrm{AChE}$ has become a key target enzyme in $\mathrm{AD}$ and has been a hot research field for the treatment of $\mathrm{AD}$ in recent years.

As shown in Figure 4c, all the extract and fractions exhibited AChE inhibitory activity in a dose-dependent manner as similar to $\alpha$-glucosidase inhibitory activity, although they were 
less active than the positive control/drug galantamine. Among them, AF exerted the strongest inhibitory effect, followed by CME, EtOAc, n-BuOH, and then PE (Figure 4d), and their $\mathrm{IC}_{50}$ values were $10.11 \pm 1.38,14.40 \pm 1.10,31.63 \pm 11.06,110.01 \pm 11.23$, and $149.56 \pm 20.08 \mu \mathrm{g} / \mathrm{mL}$, respectively. In agreement with the AF fraction, the CME of $M$. lasiocarpa also exhibited high AChE inhibitory activity. Correlation analyses showed a poor relationship of AChE inhibitory activity with other biological activities.

\subsection{Xanthine Oxidase Inhibitory Ability}

Xanthine oxidase $(\mathrm{XO})$, a key enzyme in the purine metabolism, can catalyze the oxidation of hypoxanthine to xanthine, then to uric acid, eventually leading to hyperuricemia and gout [25]. According to the Figure 4e, all the extract and fractions demonstrated substantial XO inhibitory activity compared to allopurinol as a positive control $(p<0.05)$. The $\mathrm{IC}_{50}$ values are shown in Figure $4 \mathrm{f}$ in the order of CME $(5.23 \pm 0.35)>\mathrm{PE}(7.43 \pm 3.77$ $\mu \mathrm{g} / \mathrm{mL})>\operatorname{EtOAc}(7.50 \pm 0.16 \mu \mathrm{g} / \mathrm{mL})>\mathrm{n}-\mathrm{BuOH}(12.64 \pm 1.12 \mu \mathrm{g} / \mathrm{mL})>\mathrm{AF}(14.32 \pm 2.08$ $\mu \mathrm{g} / \mathrm{mL})>$ allopurinol $(24.85 \pm 0.46 \mu \mathrm{g} / \mathrm{mL})$.

From Figure 2, the XO inhibitory activity was negatively correlated with TFC ( $r=-0.66$, $p<0.01)$. This is because flavonoids have been reported to possess the ability to act as active inhibitors of xanthine oxidase by competitively hindering the enzyme actions [26]. Beyond this, significant negative correlations between the XO inhibitory activity with FRAP and ORAC were observed $(r=-0.61$ to $-0.64, p<0.05)$.

\subsection{HPLC-MS/MS Analysis}

Based on the results of the antioxidant properties and enzyme inhibitory activities, the EtOAc fraction with the higher content of bioactive component and biological activity was selected for the HPLC-MS/MS analysis. The total ion chromatogram and the molecular structure of the compounds identified are depicted in Figure 5, and all information needed for the compound assignment is summarized in Table 2. A total of ten compounds were separated, and one phenolic acid, one terpenoid, and seven flavonoids were identified, including catechin (1), daphuribirin D (2), epicatechin derivative (3), an unknown compound (4), vaterioside A (5 or 6), 1,6,2' ,6'-tetraacetyl-3-O-pcoumaroylsucrose (7), 1,2' $3^{\prime}, 4^{\prime}, 6^{\prime}$-pentaacetyl-3-O-p-coumaroylsucrose (8), 6-methoxy$1,2^{\prime}, 3^{\prime}, 4^{\prime}, 6^{\prime}$-pentaacetyl-3-O-p-3,4,5-trihydroxy cinnamoylsucrose (9), and 1,6,2', $3^{\prime}, 4^{\prime}, 6^{\prime}$ hexaacetyl-3-O-p-coumaroylsucrose (10).

Among them, compounds 5-10 were first identified in M. lasiocarpa, and their structural formulas are shown in Figure 5B. Many of the compounds presented certain biological activities. For example, research reported the $\alpha$-glucosidase inhibitory activity and radical scavenging activity of catechin [27]. Daphuribirin D belongs to bifuranocoumarins, which has demonstrated wide-ranging bioactivities, inclusive of analgesic, anticoagulant antiHIV, anti-inflammatory, antimicrobial, antineoplastic, antioxidant, and immunomodulatory effects, due to its structural diversity [28].

Moreover, the epiatechin derivative is known as a bioactive molecule with anticancer, anti-oxidant, hepatoprotective, anti-inflammatory, and anti-microbial properties [29]. Overall, the compounds identified were mainly flavonoids, which may be responsible for the excellent antioxidant activities and $\alpha$-glucosidase inhibitory activity of the EtOAc fraction. 

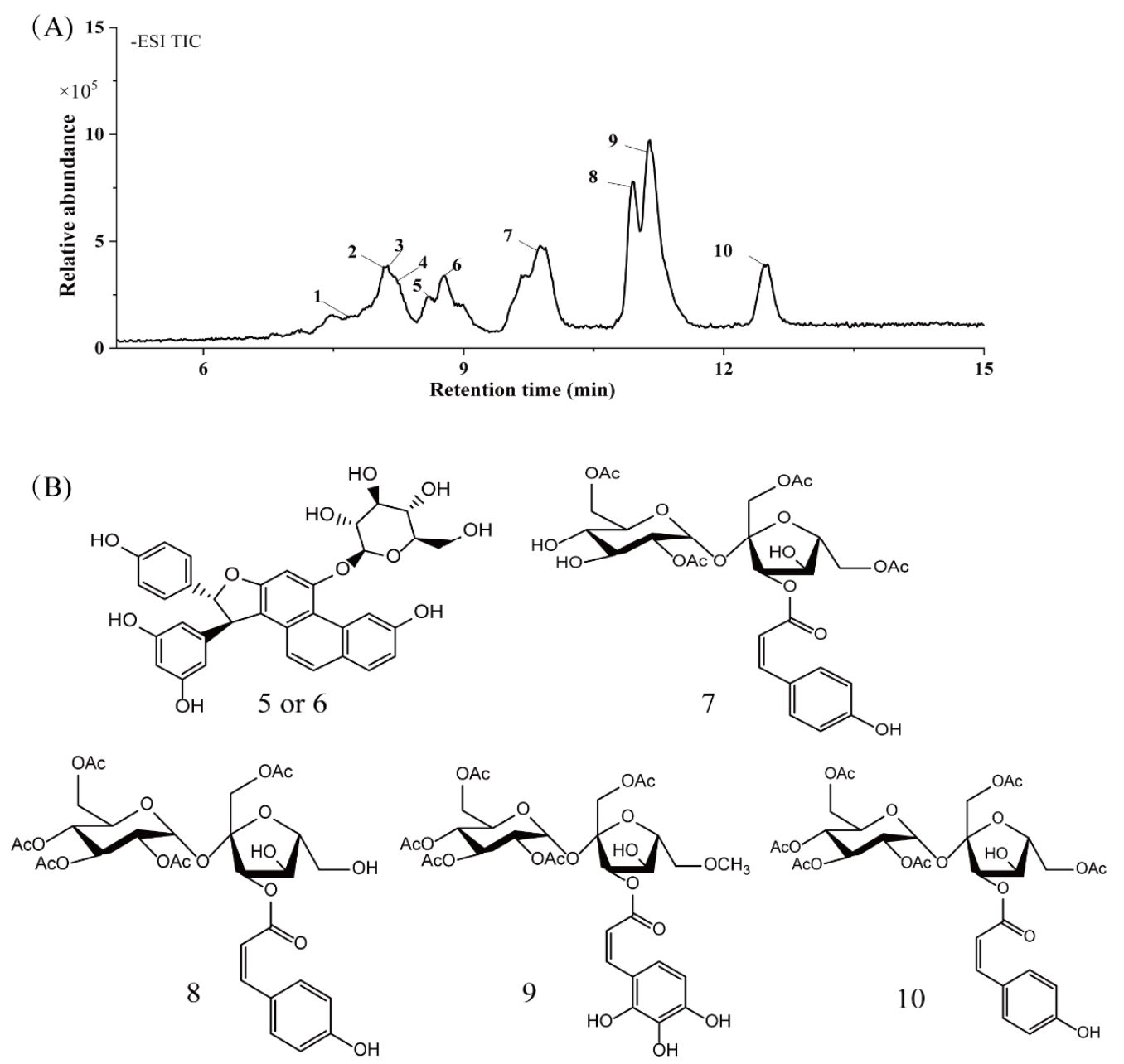

Figure 5. (A) The HPLC-MS/MS total ion current (TIC) chromatogram. The numbers 1-10 above the peaks indicate the location of the identified compounds. (B) Chemical structures of the 5-10 compounds. 5 or 6: vaterioside A; 7:

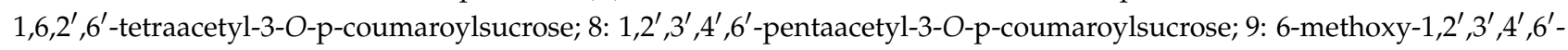
pentaacetyl-3-O-p-3,4,5-trihydroxy cinnamoyl sucrose; and 10: 1,6,2' $3^{\prime}, 4^{\prime}, 6^{\prime}$-hexaacetyl-3-O-p-coumaroylsucrose. 
Table 2. Identified or tentatively identified compounds of the EtOAc fraction of M. lasiocarpa by HPLC-MS/MS.

\begin{tabular}{|c|c|c|c|c|c|c|c|c|c|}
\hline & $\begin{array}{c}\mathrm{RT} \\
\text { (time) }\end{array}$ & $\begin{array}{c}\text { MS } \\
{[\mathrm{M}-\mathrm{H}]}\end{array}$ & $\begin{array}{c}\text { Molecular } \\
\text { Formula }\end{array}$ & Molecular Weight & $\begin{array}{c}\text { Concentration } \\
(\mathrm{ppm})\end{array}$ & $\begin{array}{c}\text { MS/MS } \\
\text { Fragments }\end{array}$ & $\begin{array}{c}\text { Name of } \\
\text { Compounds }\end{array}$ & Classification & Reference \\
\hline 1 & 7.673 & 289.0682 & $\mathrm{C}_{15} \mathrm{H}_{14} \mathrm{O}_{6}$ & 290.079 & 12.28 & 203.0789 & \multirow{4}{*}{$\begin{array}{c}\text { Catechin } \\
\text { Daphuribirin D } \\
\text { Epiatechin } \\
\text { derivative } \\
\text { unknown }\end{array}$} & Phenolic acids & [30] \\
\hline 2 & 8.056 & 571.1620 & $\mathrm{C}_{32} \mathrm{H}_{28} \mathrm{O}_{10}$ & 572.1682 & -1.8 & $117.03,145.0261,252.0938$ & & Terpenoids & [31] \\
\hline 3 & 8.129 & 723.4958 & $\mathrm{C}_{37} \mathrm{H}_{72} \mathrm{O}_{13}$ & 724.4973 & -7.98 & $207.1456,660.0386,677.4916$ & & Flavonoids & [32] \\
\hline 4 & 8.229 & 836.5792 & $\mathrm{C}_{51} \mathrm{H}_{81} \mathrm{O}_{9}$ & 837.5822 & 1.89 & $109.2067,230.8014,790.5704$ & & - & \\
\hline 5 & 8.579 & 613.1719 & $\mathrm{C}_{34} \mathrm{H}_{30} \mathrm{O}_{11}$ & 614.1788 & -0.59 & $117.0314,145.0279,146.0321$ & Vaterioside A & Flavonoids & [33] \\
\hline 6 & 8.746 & 613.1719 & $\mathrm{C}_{34} \mathrm{H}_{30} \mathrm{O}_{11}$ & 614.1788 & -0.59 & $145.0279,146.0321,163.038$ & $\begin{array}{l}\text { Vaterioside A isomer } \\
1,6,2^{\prime}, 6^{\prime} \text {-Tetracetyl- }\end{array}$ & Flavonoids & [33] \\
\hline 7 & 9.864 & 655.1833 & $\mathrm{C}_{29} \mathrm{H}_{36} \mathrm{O}_{17}$ & 656.1952 & 7.12 & $117.0334,145.0282,163.0403$ & $\begin{array}{c}\text { 3-O-p- } \\
\text { coumaroylsucrose } \\
1,2^{\prime}, 3^{\prime}, 4^{\prime}, 6^{\prime}-\end{array}$ & Flavonoids & [34] \\
\hline 8 & 10.948 & 697.1947 & $\mathrm{C}_{31} \mathrm{H}_{38} \mathrm{O}_{18}$ & 698.1985 & 5.5 & $145.0283,163.038,655.1838$ & $\begin{array}{l}\text { Pentaacetyl-3-O-p- } \\
\text { coumaroylsucrose } \\
\text { 6-Methoxy- } \\
1,2^{\prime}, 3^{\prime}, 4^{\prime}, 6^{\prime}-\end{array}$ & Flavonoids & [35] \\
\hline 9 & 11.131 & 743.1991 & $\mathrm{C}_{32} \mathrm{H}_{40} \mathrm{O}_{20}$ & 744.2113 & 6.61 & $145.028,163.0393$ & $\begin{array}{c}\text { pentaacetyl-3-O-p- } \\
3,4,5 \text {-trihydroxy } \\
\text { cinnamoylsucrose } \\
1,6,2^{\prime}, 3^{\prime}, 4^{\prime}, 6^{\prime}-\end{array}$ & Flavonoids & [36] \\
\hline 10 & 12.449 & 739.2032 & $\mathrm{C}_{33} \mathrm{H}_{40} \mathrm{O}_{9}$ & 740.2164 & 7.97 & $117.0357,145.0281,146.03$ & $\begin{array}{l}\text { Hexaacetyl-3-O-p- } \\
\text { coumaroylsucrose }\end{array}$ & Flavonoids & [37] \\
\hline
\end{tabular}




\subsection{GC-MS Analysis}

Chemical analysis of the EtOAc fraction was further performed by GC-MS. The total ion chromatogram is shown in Figure 6. According to the corresponding mass spectral databases, 15 major compounds were identified and listed in Table 3, including seven acids, one alcohol, and seven esters. The relative content was in the following order: 9-octadecenoic acid (Z)-, methyl ester (29.96\%), trans-13-octadecenoic acid (8.86\%), 9octadecenoic acid, methyl ester, (E)- (8.45\%), cis-13-eicosenoic acid, methyl ester (8.43\%), hexadecanoic acid, methyl ester $(5.16 \%)$, methyl stearate $(4.69 \%)$, eicosanoic acid ME P891 (3.65\%), hexacosyl pentafluoropropionate (3.47\%), phthalic acid, butyl hept-3-yl ester $(1.88 \%)$, cis-13-octadecenoic acid $(1.47 \%)$, methyl 9-cis,11-transoctadecadienoate $(1.06 \%)$, trans-á-santalol $(1.04 \%), 1,4$-benzenedicarboxylic acid, dimethyl ester $(0.95 \%)$, $\mathrm{n}$-hexadecanoic acid $(0.81 \%)$, cis-11-eicosenoic acid, and methyl ester $(0.78 \%)$.

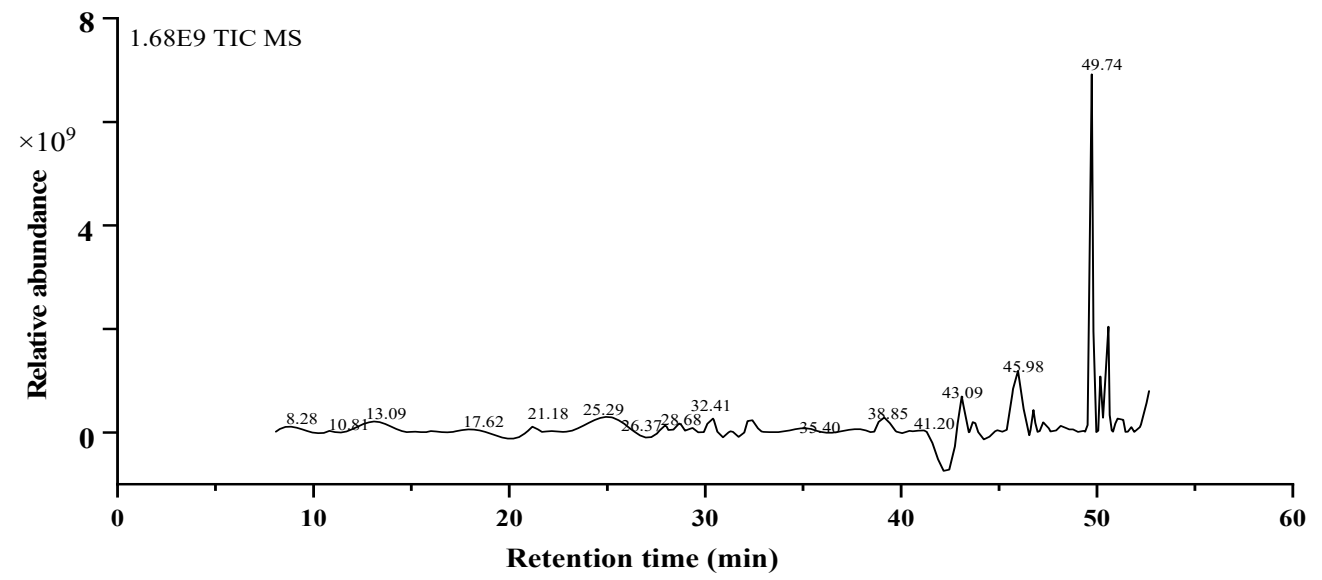

Figure 6. The GC-MS total ion current (TIC) chromatogram. The numbers above the peaks indicate the retention time for each compound.

These compounds, therefore, also might be the primary reason for the biological activities of $M$. lasiocarpa. Interestingly, the 9-octadecenoic acid (Z)-, methyl ester, was dominant in the entire GC-MS chromatogram, which was found to have antimicrobial activity, for instance, against $S$. aureus, E. coli and M. smegmatis [38]. It can be clearly speculated that fatty acid of $M$. lasiocarpa might be responsible for antifungal activity and contribute to the prevention of infectious diseases.

Table 3. The results of GC-MS analysis of the EtOAc fraction.

\begin{tabular}{|c|c|c|c|c|c|c|}
\hline & $\begin{array}{c}\mathrm{RT} \\
\text { (time) }\end{array}$ & Name of Compounds & $\begin{array}{l}\text { Molecular } \\
\text { Formula }\end{array}$ & Area & $\begin{array}{c}\text { Area } \\
(\%)\end{array}$ & Structure \\
\hline 1 & 30.44 & Trans-á-santalol & $\mathrm{C}_{15} \mathrm{H}_{24} \mathrm{O}$ & $240,544,370.50$ & 1.04 & \\
\hline 2 & 32.17 & $\begin{array}{l}\text { 1,4-Benzenedicarboxylic } \\
\text { acid, dimethyl ester }\end{array}$ & $\mathrm{C}_{10} \mathrm{H}_{10} \mathrm{O}_{4}$ & $218,812,929.34$ & 0.95 & \\
\hline 3 & 42.89 & $\begin{array}{l}\text { Cis-13-eicosenoic acid, } \\
\text { methyl ester }\end{array}$ & $\mathrm{C}_{21} \mathrm{H}_{40} \mathrm{O}_{2}$ & $1405,375,753.9$ & 8.43 & \\
\hline 4 & 43.78 & $\begin{array}{l}\text { Cis-11-eicosenoic acid, } \\
\text { methyl ester }\end{array}$ & $\mathrm{C}_{21} \mathrm{H}_{40} \mathrm{O}_{2}$ & $181,015,792.24$ & 0.78 & \\
\hline 5 & 45.72 & Eicosanoic acid ME P891 & $\mathrm{C}_{21} \mathrm{H}_{42} \mathrm{O}_{2}$ & $842,605,575.83$ & 3.65 & \\
\hline 6 & 45.97 & $\begin{array}{l}\text { Hexadecanoic acid, methyl } \\
\text { ester }\end{array}$ & $\mathrm{C}_{17} \mathrm{H}_{34} \mathrm{O}_{2}$ & $1191,145,281.60$ & 5.16 & \\
\hline 7 & 46.76 & $\begin{array}{l}\text { Phthalic acid, butyl } \\
\text { hept-3-yl ester }\end{array}$ & $\mathrm{C}_{19} \mathrm{H}_{28} \mathrm{O}_{4}$ & $434,470,530.88$ & 1.88 & \\
\hline
\end{tabular}


Table 3. Cont.

\begin{tabular}{|c|c|c|c|c|c|c|}
\hline & $\begin{array}{c}\mathrm{RT} \\
\text { (time) }\end{array}$ & Name of Compounds & $\begin{array}{l}\text { Molecular } \\
\text { Formula }\end{array}$ & Area & $\begin{array}{c}\text { Area } \\
(\%)\end{array}$ & Structure \\
\hline 8 & 46.86 & n-Hexadecanoic acid & $\mathrm{C}_{16} \mathrm{H}_{32} \mathrm{O}_{2}$ & $186,578,734.29$ & 0.81 & minster \\
\hline 9 & 49.73 & $\begin{array}{l}\text { 9-Octadecenoic acid (Z)-, } \\
\text { methyl ester }\end{array}$ & $\mathrm{C}_{19} \mathrm{H}_{36} \mathrm{O}_{2}$ & $6915,810,529.98$ & 29.96 & \\
\hline 10 & 49.82 & $\begin{array}{l}\text { 9-Octadecenoic acid, methyl } \\
\text { ester, (E)- }\end{array}$ & $\mathrm{C}_{19} \mathrm{H}_{36} \mathrm{O}_{2}$ & $1950,734,475.62$ & 8.45 & \\
\hline 11 & 50.17 & Methyl stearate & $\mathrm{C}_{19} \mathrm{H}_{38} \mathrm{O}_{2}$ & $1083,118,959.91$ & 4.69 & \\
\hline 12 & 50.58 & trans-13-Octadecenoic acid & $\mathrm{C}_{18} \mathrm{H}_{34} \mathrm{O}_{2}$ & $2044,402,879.86$ & 8.86 & \\
\hline 13 & 50.65 & cis-13-Octadecenoic acid & $\mathrm{C}_{18} \mathrm{H}_{34} \mathrm{O}_{2}$ & $338,345,248.07$ & 1.47 & \\
\hline 14 & 51.35 & $\begin{array}{c}\text { Methyl 9-cis,11- } \\
\text { transoctadecadienoate }\end{array}$ & $\mathrm{C}_{19} \mathrm{H}_{34} \mathrm{O}_{2}$ & $243,690,268.64$ & 1.06 & \\
\hline 15 & 52.66 & $\begin{array}{c}\text { Hexacosyl } \\
\text { pentafluoropropionate }\end{array}$ & $\mathrm{C}_{29} \mathrm{H}_{53} \mathrm{~F}_{5} \mathrm{O}_{2}$ & $802,126,926.87$ & 3.47 & \\
\hline
\end{tabular}

\section{Discussion}

Despite being a flower with high cultural, edible, medicinal, and ornamental values, the chemical components and bioactivities of $M$. lasiocarpa have been scarcely evaluated. In this study, the crude methanol extract of $M$. lasiocarpa and its fractions by solvents of different polarities were prepared. The TPC, TFC, and antioxidant activities, including the DPPH and ABTS radical scavenging capacity, FRAP, and ORAC of the extract and fractions were determined. The therapeutic potential in the treatment of diabetes, Alzheimer's disease, and hyperuricemia were assessed by testing its inhibitory effect on $\alpha$-glucosidase, acetylcholinesterase, and xanthine oxidase. Finally, the chemical compositions of the fraction with the best biological activity were investigated using both HPLC-MS/MS and GC-MS techniques.

Among all the fractions, EtOAc possessed the highest bioactive component content and better biological activity. In addition to the highest TPC and higher TFC, its $\mathrm{IC}_{50}$ values of the DPPH and ABTS radical scavenging abilities, FRAP values, and ORAC values were significantly higher than the other fractions, which were comparable if not better than that of the positive control Vc. Furthermore, each other fraction had different degrees of antioxidant activity. As reported in several works of literature, the antioxidant activity of the plant extracts is correlated with their total phenolic content and total flavonoid content, and the solvents system has great effects on the phenolic, flavonoid contents, and antioxidant activities [39-41].

For the $\alpha$-glucosidase, acetylcholinesterase, and xanthine oxidase inhibitory abilities, the EtOAc, AF, and CME fractions displayed the strongest activity, respectively. Previous studies showed that a few edible or medicinal plants, including hawthorn fruit [42], Lycopodiastrum casuarinoides [43], and Corchorus depressus [44], were reported with $\alpha$-glucosidase and $\mathrm{AChE}$ inhibitory activities, in agreement with M. lasiocarpa. In combination, these three fractions exhibited relatively strong activity in these three enzyme inhibition experiments, which may be related to their higher phenolic or flavonoid contents [45].

By using HPLC-MS/MS and GC-MS approaches, a total of 9 and 15 compounds were identified in the EtOAc fraction, respectively. Compared to the previous studies $[4,7]$, more new compounds in M. lasiocarpa were identified. Most of them were flavonoids, which also explains the higher $\alpha$-glucosidase and acetylcholinesterase inhibitory abilities of the EtOAc fraction as the results showed a highly significant correlation of TFC with the $\alpha$-glucosidase, acetylcholinesterase, and xanthine oxidase inhibitory abilities.

In summary, $M$. lasiocarpa exhibited excellent antioxidant activity, $\alpha$-glucosidase, acetylcholinesterase, and xanthine oxidase inhibition activities, especially for its EtOAc 
fraction, which may be related to its high contents of phenolic and flavonoid compounds. The results suggest that $M$. lasiocarpa has the potential to be exploited as a natural source of preventive agent for diabetes mellitus, Alzheimer's disease, and gout [21-25].

However, considering that these data were obtained from in vitro assays, these extract and fractions without digestion treatment would be unlikely to maintain the chemicals and activities from ingestion until arriving at the target organ in addition to the isolation and purification of the actual active compounds. Additional in vivo experiments are needed to determine and confirm the biological uses before proceeding to human intervention.

\section{Materials and Methods}

\subsection{Standards and Reagents}

The 2,2'-azino-bis-(3-ethylbenzothiazoline-6-sulfonic acid) (ABTS), 2,2-diphenyl-1-picrylhy drazyl (DPPH), 2,4,6-Tris(2-pyridyl)-s-triazine (TPTZ), 2,2'-azobis(2-amidinopropane) dihydrochloride (AAPH), fluorescein sodium, acetylthiocholine iodide, vitamin C (Vc), and 2,6-ditert-butyl-4-methylphenol (BHT) were obtained from Aladdin Biotechnology (analytical grade, China). Other analytical grade chemicals, including methanol, petroleum ether, ethyl acetate, and n-butanol were purchased from Sinopharm Chemical Reagent Co., Ltd. (Shanghai, China).

Chromatographic acetonitrile was purchased from Merck (Darmstadt, Germany). $\alpha$ glucosidase (from saccharomyces cerevisiae), xanthine oxidase (XO), acetylcholinesterase (AChE), acarbose, galantamine (GALM), allopurinol, 4-methylumbelliferyl- $\beta$-D glucuronide (4-MUG), 5,5'-dithiobis (2-nitrobenzoic acid) (DTNB), and acetylthiocholine iodide (ATCI) were purchased from Sigma-Aldrich (St. Louis, MO, USA).

\subsection{Sample Preparation}

Plants of M. lasiocarpa were collected in Southwest Forestry University, Kunming, Yunnan Province, China, in August 2016. After collection, the flowers of M. lasiocarpa were immediately transferred into a cool box with ice blocks before transportation to the laboratory. The samples were stored at $-80^{\circ} \mathrm{C}$ and then freeze-dried and smashed into powder. The powdered sample $(100 \mathrm{~g})$ was mixed with $2 \mathrm{~L}$ of $70 \%$ methanol, followed by an ultrasonic extraction for $1 \mathrm{~h}$ at $50^{\circ} \mathrm{C}$ with an ultrasonic power of $300 \mathrm{~W}$. After centrifugation at $4000 \mathrm{rpm}$ for $20 \mathrm{~min}$, the filtration residue was re-extracted again.

The supernatants were combined and evaporated under a vacuum at $50{ }^{\circ} \mathrm{C}$ to yield the crude methanol extract (CME). Then, the CME was dissolved in $500 \mathrm{~mL} \mathrm{H}_{2} \mathrm{O}$ and fractionated via liquid-liquid partitioning with solvents of different polarities successively at a 1:1 volume ratio, finally producing the petroleum ether (PE) fraction, ethyl acetate $(\mathrm{EtOAc})$ fraction, $\mathrm{n}$-butanol $(\mathrm{n}-\mathrm{BuOH})$ fraction, and aqueous fraction $(\mathrm{AF})$. All the extract and fractions were stored at $-18{ }^{\circ} \mathrm{C}$ until further use.

\subsection{Total Phenolic and Flavonoid Contents}

The total phenolic content (TPC) was determined by the Folin-Ciocalteu method [46]. Briefly, a $40 \mu \mathrm{L}$ sample at appropriate concentration and $25 \mu \mathrm{L}$ of Folin-Ciocalteu reagent were mixed in a 96-well microplate, and then $200 \mu \mathrm{L}$ of $7.5 \% \mathrm{Na}_{2} \mathrm{CO}_{3}$ solution $(w / v)$ was added and kept in the dark at room temperature for $25 \mathrm{~min}$. The absorbance at $765 \mathrm{~nm}$ was determined, and the TPC was counted from a calibration curve plotted against gallic acid $(20-100 \mu \mathrm{g} / \mathrm{mL})$. The results were expressed as $\mathrm{mg}$ of gallic acid equivalents per $\mathrm{g}$ of dry extract (mg GAE/g DE).

The total flavonoid content (TFC) was measured using the $\mathrm{AlCl}_{3}$ colorimetric method [47]. A $100 \mu \mathrm{L}$ suitable concentration of sample solution was pipetted onto a 96-well plate, then $100 \mu \mathrm{L} \mathrm{AlCl}{ }_{3} \cdot 6 \mathrm{H}_{2} \mathrm{O}$ solution (2\%) was added, and the absorbance was measured at $430 \mathrm{~nm}$ after $6 \mathrm{~min}$. Quercetin $(2.0-12.0 \mu \mathrm{g} / \mathrm{mL})$ was used as the standard, and the results are expressed as $\mathrm{mg}$ of quercetin equivalents per $\mathrm{g}$ of dry extract (mg QE/g DE). 


\subsection{Antioxidant Activity Determination}

\subsubsection{DPPH Radical Scavenging Activity}

The DPPH. scavenging activity was assessed by referring to the reported method [48]. A $100 \mu \mathrm{L}$ properly diluted sample solution was mixed with $100 \mu \mathrm{L}$ of DPPH solution $(0.15 \mathrm{mmol} / \mathrm{L})$ on a 96-well plate, after storing at room temperature in dim light for $30 \mathrm{~min}$, and then the absorbance value $(A s)$ was read at $517 \mathrm{~nm}$. Methanol was used to replace the sample as a negative control $(A b)$, while $\mathrm{V}_{\mathrm{c}}$ and BHT were the positive controls. The percentage of DPPH radical clearance was calculated using the following Formula (1), and the DPPH. scavenging activity was expressed as the $\mathrm{IC}_{50}$ value $(\mu \mathrm{g} / \mathrm{mL})$, which was obtained by plotting the percentage of scavenging versus the concentration.

$$
\text { DPPH radical scavenging rate }(\%)=[(A b-A s) / A b] \times 100 \%
$$

\subsubsection{ABTS Radical Scavenging Activity}

The ABTS.+ ${ }^{+}$scavenging activity assay was performed as described by Arts et al. [49]. The ABTS solution $(7 \mathrm{mM})$ was mixed with potassium sulfate $(2.45 \mathrm{mM})$ and incubated for $12 \mathrm{~h}$ at room temperature in the dark. Before the assay, the ABTS working solution was diluted with methanol to the absorbance of $0.70 \pm 0.02$ at $734 \mathrm{~nm}$. A $50-\mu \mathrm{L}$ appropriate concentration of sample solution was mixed with $200 \mu \mathrm{L}$ of ABTS working solution on a 96-well plate and kept for $6 \mathrm{~min}$ at room temperature, and then the absorbance at 734 $\mathrm{nm}$ was measured. Methanol was used instead of the sample as a negative control $(A b)$, while Vc and BHT were used as positive controls. The scavenging rates were calculated according to Equation (1), and the results are expressed as $\mathrm{IC}_{50}$ values $(\mu \mathrm{g} / \mathrm{mL})$.

\subsubsection{Ferric Reducing Antioxidant Power Assay}

The ferric reducing antioxidant power (FRAP) method was carried out according to the method of [50]. TPTZ $(10 \mathrm{mM}), \mathrm{FeCl}_{2}(20 \mathrm{mM})$, and acetate buffer $(300 \mathrm{mM})$ were mixed in the ratio of 1:1:10 to prepare a fresh working FRAP reagent. A 20- $\mu \mathrm{L}$ sample solution with a suitable concentration and $300 \mu \mathrm{L}$ FRAP working solution were loaded onto a 96-well plate, and the absorbance was read at $593 \mathrm{~nm}$ after incubation for $10 \mathrm{~min}$ at $37^{\circ} \mathrm{C}$. Methanol was used as a negative control, and Vc and BHT $(40 \mu \mathrm{g} / \mathrm{mL})$ were used as positive controls. Ferrous sulfate $(20-100 \mu \mathrm{g} / \mathrm{mL})$ was taken as a standard for the preparation of the standard curve, and the FRAP value was expressed as mg of $\mathrm{FeSO}_{4}$ per gram of dry extract ( $\left.\mathrm{mg} \mathrm{FeSO}_{4} / \mathrm{g} \mathrm{DE}\right)$.

\subsubsection{Oxygen Radical Absorbance Capacity (ORAC) Assay}

The ORAC was performed as recommended by a previous report of Huang [51]. A $25-\mu \mathrm{L}$ properly diluted sample was mixed with $200 \mu \mathrm{L}$ of fluorescein on a black 96 -well fluorescence microplate at $37^{\circ} \mathrm{C}$ for $10 \mathrm{~min}$, and then $50 \mu \mathrm{L}$ of AAPH was added into each well. The fluorescence generated was read at $535 \mathrm{~nm}$ emission and $485 \mathrm{~nm}$ excitation every $1.5 \mathrm{~min}$ for $2 \mathrm{~h}$ using a fluorescence microplate reader. Trolox $(10-100 \mu \mathrm{g} / \mathrm{mL})$ was used as the standard. Methanol was used as a negative control, and Vc and BHT were used as positive controls. The results of ORAC values were calculated using the area under the curve (AUC) with the Trolox standard curve and are expressed as mg of Trolox equivalents (TE)/g dry extract (mg TE/g DE).

\subsection{Enzyme Inhibitory Ability \\ 4.5.1. Inhibition of $\alpha$-Glucosidase}

The $\alpha$-glucosidase inhibitory activity was evaluated following a previous method [52]. A $50-\mu \mathrm{L}$ suitably diluted sample solution was mixed with $50 \mu \mathrm{L}$ of $\alpha$-glucosidase $(0.1 \mathrm{U} / \mathrm{mL}$, $\mathrm{pH}=6.9)$ in a black microtiter 96-well plate and incubated for $10 \mathrm{~min}$ at $25^{\circ} \mathrm{C}$. Then, $50 \mu \mathrm{L}$ of 4-MUG $(0.84 \mathrm{mM})$ was added and incubated for $25 \mathrm{~min}$ at $25^{\circ} \mathrm{C}$.

The reaction was then terminated by adding a $100 \mu \mathrm{L}$ glycine- $\mathrm{NaOH}$ buffer $(100 \mathrm{mM}$, $\mathrm{pH}$ 10.6). After shaking on an orbital shaker for $30 \mathrm{~s}$, the fluorescence was measured at $\lambda \mathrm{ex}$ 
$355 \mathrm{~nm}$ and $\lambda$ ex $460 \mathrm{~nm}$. Methanol was used as a negative control, and acarbose was used as a positive control. The $\alpha$-glucosidase inhibitory ability was expressed as the $\mathrm{IC}_{50}$ value $(\mu \mathrm{g} / \mathrm{mL})$. The $\alpha$-glucosidase inhibition rate was counted as follows:

$$
\text { Inhibition rate }(\%)=\frac{A b-(A s-A c)}{A b} \times 100 \%
$$

where $A b, A s$, and $A c$, respectively, represent the fluorescence values of the reagent blank (without sample), test samples (with all reagents), and negative control (without $\alpha$-glucosidase).

\subsubsection{Inhibition of Acetylcholinesterase}

The acetylcholinesterase (AChE) inhibitory activity assay was measured by the Ellman colorimetric method [53]. A 50- $\mu \mathrm{L}$ appropriate diluted sample solution, $20 \mu \mathrm{L}$ of acetylcholine $(0.2 \mathrm{U} / \mathrm{mL})$, and $90 \mu \mathrm{L}$ of Ellman's reagent (containing $15 \mu \mathrm{L}$ of $15 \mathrm{mM}$ ATCI and $75 \mu \mathrm{L}$ of $3 \mathrm{mM}$ DTNB) were added to a 96-well plate in darkness for $10 \mathrm{~min}$. Finally, $20 \mu \mathrm{L}$ of $0.2 \mathrm{U} / \mathrm{mL}$ AChE was added and kept in darkness for $5 \mathrm{~min}$, and the absorbance was read at $405 \mathrm{~nm}(A s)$. Methanol in place of the sample was used as a blank $(A b)$, phosphate buffer in place of acetylcholine was used as a negative control $(A c)$, and galanthamine was used as a positive control. The inhibition rate calculated was similar to Equation (2).

\subsubsection{Inhibition of Xanthine Oxidase}

The method for measuring the xanthine oxidase $(X O)$ inhibitory activity was slightly modified from a previous method [54]. A 50- $\mu \mathrm{L}$ sample, $60 \mu \mathrm{L}$ phosphate buffer $(70 \mathrm{mM}$, $\mathrm{PH}=7.5$ ), and $50 \mu \mathrm{L}$ of $\mathrm{XO}$ were mixed for $15 \mathrm{~min}$ at $25^{\circ} \mathrm{C}$, and the reaction was started by the addition of $60 \mu \mathrm{L}$ xanthine solution $(1.5 \mathrm{mM})$. After incubation for $8 \mathrm{~min}$ at $25^{\circ} \mathrm{C}$, the absorbance was read at $295 \mathrm{~nm}(A s)$. Methanol was used as the reagent blank $(A b)$, and phosphate buffer was used as a negative control $(A c)$. Allopurinol was used as a positive control. The XO inhibitory ability was expressed as the $\mathrm{IC}_{50}$ value $(\mu \mathrm{g} / \mathrm{mL})$.

\subsection{HPLC-MS/MS Analysis}

The HPLC-MS/MS analysis was performed according to the previously described method [55]. The equipment consisted of an Agilent1290 UPLC coupled to a diode array detector, a triple quadruple-ion trap mass analyzer, an electrospray ionization (ESI) source, and an Agilent Technologies 6538 OHD Accurate Mass MS/MS system (Agilent Technologies, CA, USA). The separation was performed by Agilent ZORBAX SB-C18 $(4.6 \times 250 \mathrm{~mm}, 5 \mu \mathrm{m})$ column, with mobile phase A (deionized water $+0.1 \%$ formic acid) and mobile phase B (acetonitrile). To obtain the best separation in a short time, the gradient program and flow rate were optimized.

The optimum linear-gradient started with $10 \% \mathrm{~B}$ and the conditions of the mobile phase B were: 0-10 min, 15\% B; 10-20 min, 20\% B; 20-30 min, 27\% B; 30-40 min, 40\% $\mathrm{B}$, and finally the column was washed with $100 \%$ B for $5 \mathrm{~min}$. After filtering through a $0.45 \mu \mathrm{m}$ membrane, $20 \mu \mathrm{L}$ of the sample was injected into the system. UV spectra from 200 to $400 \mathrm{~nm}$ were recorded for peak characterization. The automatic MS/MS experiment was fragmented by adjusting the collision energy as follows: $m / z<200,10$, and $20 \mathrm{eV}$; $m / z$ 200-400, 20, and $30 \mathrm{eV} ; m / z$ 400-600, 30, and $40 \mathrm{eV} ; m / z>600,40$, and $50 \mathrm{eV}$; and $m / z>700,40,50$, and $60 \mathrm{eV}$.

The MS data were processed with MassHunter software (Agilent Technologies, Santa Clara, CA, USA) and searched using the Generate Molecular Formula ${ }^{\mathrm{TM}}$ editor to obtain the possible molecular formula of each precursor and product. The compound at each peak was identified according to its precursor ion, molecular weight, fragmentation pattern, and retention time, and we matched these data with that reported in available references. 


\subsection{GC-MS Analysis}

The fraction with the best biological activity was analyzed with gas chromatography coupled to a mass spectrometer (GC-MS, Trace1300/ISQ, Thermo Fisher, Waltham, MA, USA) [56]. A capillary HP- 5 column $(30.00 \mathrm{~m} \times 0.25 \mathrm{~mm} \times 0.25 \mu \mathrm{m})$ was used for sample separation. The injector temperature and injection volume were $250^{\circ} \mathrm{C}$ and $1 \mu \mathrm{L}$, respectively. The initial temperature was $50^{\circ} \mathrm{C}$ for $2 \mathrm{~min}$, followed by an increase of $3{ }^{\circ} \mathrm{C} / \mathrm{min}$ up to $160^{\circ} \mathrm{C}$, after which it increased to $220^{\circ} \mathrm{C}$ with $5{ }^{\circ} \mathrm{C} / \mathrm{min}$. Helium was used as carrier gas with a flow rate of $1 \mathrm{~mL} / \mathrm{min}$, and the ionization energy was $70 \mathrm{eV}$.

\subsection{Statistical Analysis}

All data are presented as the mean \pm standard deviation (SD) with triplicate analyses of the same sample. Correlation analyses were performed using SPSS Version 22.0 by multiple linear regression. $p<0.05$ was considered as significant $(*)$, and $p<0.01$ was highly significant $(* *)$. The $\mathrm{IC}_{50}$ values were calculated with the polynomial fit using Origin 2018 software.

Author Contributions: Methodology, R.L. and Z.W.; software, Y.R.; validation, Y.R. and R.L.; formal analysis, Z.W.; data curation, R.L.; writing—original draft preparation, R.L.; writing-review and editing, K.-W.K. and Z.W.; visualization, T.Z.; supervision, Z.W.; project administration, X.H. and X.Z.; funding acquisition, X.H. All authors have read and agreed to the published version of the manuscript.

Funding: This research was funded by the China Agriculture Research System (grant number CARS21), National Natural Science Foundation of China (grant number 31760440), and Guangxi Key Laboratory of Fruits and Vegetables Storage-Processing Technology (grant number GXKLFV003).

Institutional Review Board Statement: "Not applicable" for studies not involving humans or animals. Informed Consent Statement: Not applicable.

Data Availability Statement: The remaining data are available on request from the corresponding author.

Acknowledgments: The authors thank the support of the College of Life Sciences, Southwest Forestry University.

Conflicts of Interest: The authors declare no conflict of interest.

Sample Availability: Samples of the compounds 1-3, 4-10 and 11-25 are available from the authors.

\section{References}

1. Ma, H.; Pan, Q.; Wang, L.; Li, Z.; Wan, Y.; Liu, X. Musella lasiocarpa var. rubribracteata (Musaceae), a New Variety from Sichuan, China. Novon J. Bot. Nomencl. 2011, 21,349-353. [CrossRef]

2. Novák, P.; Hřibová, E.; Neumann, P.; Koblížková, A.; Doležel, J.; Macas, J. Genome-wide analysis of repeat diversity across the family Musaceae. PLoS ONE 2014, 9, e98918. [CrossRef] [PubMed]

3. Christelová, P.; Valárik, M.; Hřibová, E.; De Langhe, E.; Doležel, J. A multi gene sequence-based phylogeny of the Musaceae (banana) family. BMC Evol. Biol. 2011, 11, 103. [CrossRef] [PubMed]

4. Dong, L.-B.; He, J.; Li, X.-Y.; Wu, X.-D.; Deng, X.; Xu, G.; Peng, L.-Y.; Zhao, Y.; Li, Y.; Gong, X.; et al. Chemical constituents from the aerial parts of Musella lasiocarpa. Nat. Prod. BioProspect. 2011, 1, 41-47. [CrossRef]

5. Long, C.; Ahmed, S.; Wang, X.; Liu, Y.; Long, B.; Yang, C.; Shi, Y.; Li, X.; Guo, R. Why Musella lasiocarpa (Musaceae) is Used in Southwest China to Feed Pigs. Econ. Bot. 2008, 62, 182-186. [CrossRef]

6. Liu, A.-Z.; Kress, W.J.; Long, C.-L. The ethnobotany of Musella lasiocarpa (Musaceae), an endemic plant of southwest China. Econ. Bot. 2003, 57, 279-281. [CrossRef]

7. Qin, B.; Lu, R.H.; Wang, H.Q.; Wang, M. Chemical Constituents from Musella lasiocarpa (Franchet) C. Y. Wu. Nat. Prod. Res. Dev. 2000, 12, 41-44.

8. Yang, W.L.; Tian, J.; Bai, B.R.; Guan, J.F.; Ding, L.S. Chemical constituents of Musella lasiocarpa. Chin. Tradit. Herb. Drugs 2001, 32, 681-683.

9. Zhang, W.; Hu, X.; Shen, Q.; Xing, D. Mitochondria-specific drug release and reactive oxygen species burst induced by polyprodrug nanoreactors can enhance chemotherapy. Nat. Commun. 2019, 10, 1704. [CrossRef]

10. Petersen, R.C. Alzheimer's disease: Progress in prediction. Lancet Neurol. 2010, 9, 4-5. [CrossRef] 
11. Ummat, V.; Tiwari, B.K.; Jaiswal, A.K.; Condon, K.; Garcia-Vaquero, M.; O’Doherty, J.; O’Donnell, C.; Rajauria, G. Optimisation of Ultrasound Frequency, Extraction Time and Solvent for the Recovery of Polyphenols, Phlorotannins and Associated Antioxidant Activity from Brown Seaweeds. Mar. Drugs 2020, 18, 250. [CrossRef]

12. Chen, J.; Yang, H.; Sheng, Z. Ellagic Acid Activated PPAR Signaling Pathway to Protect Ileums Against Castor Oil-Induced Diarrhea in Mice: Application of Transcriptome Analysis in Drug Screening. Front. Pharmacol. 2020, 10, 1681. [CrossRef] [PubMed]

13. Kushairi, N.; Phan, C.W.; Sabaratnam, V.; David, P.; Naidu, M. Lion's Mane Mushroom, Hericium erinaceus (Bull.: Fr.) Pers. Suppresses $\mathrm{H}(2) \mathrm{O}(2)$-Induced Oxidative Damage and LPS-Induced Inflammation in HT22 Hippocampal Neurons and BV2 Microglia. Antioxidants 2019, 8, 261. [CrossRef]

14. Ben Mefteh, F.; Daoud, A.; Chenari Bouket, A.; Thissera, B.; Kadri, Y.; Cherif-Silini, H.; Eshelli, M.; Alenezi, F.N.; Vallat, A.; Oszako, T.; et al. Date Palm Trees Root-Derived Endophytes as Fungal Cell Factories for Diverse Bioactive Metabolites. Int. J. Mol. Sci. 2018, 19, 1986. [CrossRef] [PubMed]

15. Yu, L.; Zhao, M.; Wang, J.S.; Cui, C.; Yang, B.; Jiang, Y.; Zhao, Q. Antioxidant, immunomodulatory and anti-breast cancer activities of phenolic extract from pine (Pinus massoniana Lamb) bark. Innov. Food Sci. Emerg. Technol. 2008, 9, 122-128. [CrossRef]

16. Prior, R.L.; Wu, X.; Schaich, K. Standardized Methods for the Determination of Antioxidant Capacity and Phenolics in Foods and Dietary Supplements. J. Agric. Food Chem. 2005, 53, 4290-4302. [CrossRef] [PubMed]

17. Yao, F.; Xue, Q.; Li, K.; Cao, X.; Sun, L.; Liu, Y. Phenolic Compounds and Ginsenosides in Ginseng Shoots and Their Antioxidant and Anti-Inflammatory Capacities in LPS-Induced RAW264.7 Mouse Macrophages. Int. J. Mol. Sci. 2019, 20, 2951. [CrossRef]

18. Li, Y.; Guo, C.; Yang, J.; Wei, J.; Xu, J.; Cheng, S. Evaluation of antioxidant properties of pomegranate peel extract in comparison with pomegranate pulp extract. Food Chem. 2006, 96, 254-260. [CrossRef]

19. Baek, S.H.; Nam, I.J.; Kwak, H.S.; Kim, K.C.; Lee, S.H. Cellular Anti-Melanogenic Effects of a Euryale ferox Seed Extract Ethyl Acetate Fraction via the Lysosomal Degradation Machinery. Int. J. Mol. Sci. 2015, 16, 9217-9235. [CrossRef]

20. Pimentel, F.B.; Cermeño, M.; Kleekayai, T.; Harnedy-Rothwell, P.A.; Fernandes, E.; Alves, R.C.; Oliveira, M.B.P.P.; FitzGerald, R.J. Enzymatic Modification of Porphyra dioica-Derived Proteins to Improve their Antioxidant Potential. Molecules 2020, 25, 2838. [CrossRef]

21. Dan, W.-J.; Zhang, Q.; Zhang, F.; Wang, W.-W.; Gao, J.-M. Benzonate derivatives of acetophenone as potent $\alpha$-glucosidase inhibitors: Synthesis, structure-activity relationship and mechanism. J. Enzym. Inhib. Med. Chem. 2019, 34, 937-945. [CrossRef]

22. Ofosu, F.K.; Elahi, F.; Daliri, E.B.-M.; Chelliah, R.; Ham, H.J.; Kim, J.-H.; Han, S.-I.; Hur, J.H.; Oh, D.-H. Phenolic Profile, Antioxidant, and Antidiabetic Potential Exerted by Millet Grain Varieties. Antioxidants 2020, 9, 254. [CrossRef]

23. Kohelová, E.; Peřinová, R.; Maafi, N.; Korábečný, J.; Hulcová, D.; Mař́ková, J.; Kučera, T.; Martínez González, L.; Hrabinova, M.; Vorčáková, K.; et al. Derivatives of the $\beta$-Crinane Amaryllidaceae Alkaloid Haemanthamine as Multi-Target Directed Ligands for Alzheimer's Disease. Molecules 2019, 24, 1307. [CrossRef]

24. Laspas, P.; Zhutdieva, M.B.; Brochhausen, C.; Musayeva, A.; Zadeh, J.K.; Pfeiffer, N.; Xia, N.; Li, H.; Wess, J.; Gericke, A. The $\mathrm{M}(1)$ muscarinic acetylcholine receptor subtype is important for retinal neuron survival in aging mice. Sci. Rep. $2019,9,5222$. [CrossRef] [PubMed]

25. Li, X.; Yan, Z.; Carlström, M.; Tian, J.; Zhang, X.; Zhang, W.; Wu, S.; Ye, F. Mangiferin Ameliorates Hyperuricemic Nephropathy Which Is Associated With Downregulation of AQP2 and Increased Urinary Uric Acid Excretion. Front. Pharmacol. 2020, 11, 49. [CrossRef]

26. Abdulhafiz, F.; Mohammed, A.; Kayat, F.; Bhaskar, M.; Hamzah, Z.; Podapati, S.K.; Reddy, L.V. Xanthine Oxidase Inhibitory Activity, Chemical Composition, Antioxidant Properties and GC-MS Analysis of Keladi Candik (Alocasia longiloba Miq). Molecules 2020, 25, 2658. [CrossRef] [PubMed]

27. Sabbagh, F.; Kiarostami, K.; Mahmoudi Khatir, N.; Rezania, S.; Muhamad, I.I. Green Synthesis of Mg(0.99) Zn(0.01)O Nanoparticles for the Fabrication of K-Carrageenan/NaCMC Hydrogel in order to Deliver Catechin. Polymers 2020, 12, 861. [CrossRef]

28. Sarker, S.D.; Nahar, L. Progress in the chemistry of naturally occurring coumarins. Prog. Chem. Org. Nat. Prod. 2017, 106, 241-304.

29. Ferdosian, F.; Ebadi, M.; Mehrabian, R.Z.; Golsefidi, M.A.; Moradi, A.V. Application of Electrochemical Techniques for Determining and Extracting Natural Product (EgCg) by the Synthesized Conductive Polymer Electrode (Ppy/Pan/rGO) Impregnated with Nano-Particles of $\mathrm{TiO}_{2}$. Sci. Rep. 2019, 9, 3940. [CrossRef] [PubMed]

30. Alimova, D.; Kuliev, Z.; Vdovin, A. Catechins and proanthocyanidines from Alhagi pseudoalhagi. Chem. Nat. Compd. 2007, 43, 326-327. [CrossRef]

31. Wang, N.-H.; Yoshizaki, K.; Baba, K. Seven new bifuranocoumarins, dahuribirin AG, from Japanese Bai Zhi. Chem. Pharm. Bull. 2001, 49, 1085-1088. [CrossRef] [PubMed]

32. Zhang, L.; Zhu, M.-F.; Tu, Z.-C.; Zhao, Y.; Wang, H.; Li, G.-J.; Sha, X.-M. a-Glucosidase inhibition, anti-glycation and antioxidant activities of Liquidambar formosana Hance leaf, and identification of phytochemical profile. S. Afr. J. Bot. 2017, 113, $239-247$. [CrossRef]

33. Ito, T.; Masuda, Y.; Abe, N.; Oyama, M.; Sawa, R.; Takahashi, Y.; Chelladurai, V.; Iinuma, M. Chemical constituents in the leaves of Vateria indica. Chem. Pharm. Bull. 2010, 58, 1369-1378. [CrossRef] [PubMed]

34. Mitani, T.; Horinishi, A.; Kishida, K.; Kawabata, T.; Yano, F.; Mimura, H.; Inaba, N.; Yamanishi, H.; Oe, T.; Negoro, K. Phenolics profile of mume, Japanese apricot (Prunus mume Sieb. et Zucc.) fruit. Biosci. Biotechnol. Biochem. 2013, 77, 1623-1627. [CrossRef] 
35. Jacobs, H.; Koek, G.H.; Peters, R.; Moalin, M.; van der Vij, W.J.; Bast, A.; Haen, G.R.; Tack, J.; van der Vijgh, W.J.; Haenen, G.R. Differences in the metabolicp the antioxidant flavonoid hydroxyethyl)-rutoside and mice. Possible imp cardioprotective. Antioxid. Flavonoid 2011, 7, 107-127.

36. Alvarez-Parrilla, E. Cinética de secado y efecto de la temperatura sobre las características físicas y compuestos fenólicos de chile jalapeño rojo (Capsicum annuum L.). Inst. Cienc. Biomédicas 2019, 21, 139-147. [CrossRef]

37. Han, Q.-B.; Xu, H.-X. Caged Garcinia xanthones: Development since 1937. Curr. Med. Chem. 2009, 16, 3775-3796. [CrossRef]

38. Alkooranee, J.T.; Al-khshemawee, H.H.; Al-badri, M.A.K.; Al-srai, M.S.; Daweri, H.H. Antifungal activity and GC-MS detection of leaves and roots parts of Chenopodium album extract against some phytopathogenic fungi. Indian J. Agric. Res. 2020, 54, 117-121. [CrossRef]

39. Adisakwattana, S.; Ruengsamran, T.; Kampa, P.; Sompong, W. In Vitro inhibitory effects of plant-based foods and their combinations on intestinal $\alpha$-glucosidase and pancreatic $\alpha$-amylase. BMC Complement. Altern. Med. 2012, 12, 110. [CrossRef] [PubMed]

40. Olennikov, D.N.; Kashchenko, N.I.; Chirikova, N.K.; Akobirshoeva, A.; Zilfikarov, I.N.; Vennos, C. Isorhamnetin and Quercetin Derivatives as Anti-Acetylcholinesterase Principles of Marigold (Calendula officinalis) Flowers and Preparations. Int. J. Mol. Sci. 2017, 18, 1685. [CrossRef] [PubMed]

41. Gawlik-Dziki, U.; Dziki, L.; Anisiewicz, J.; Habza-Kowalska, E.; Sikora, M.; Dziki, D. Leaves of White Beetroot As a New Source of Antioxidant and Anti-Inflammatory Compounds. Plants 2020, 9, 944. [CrossRef] [PubMed]

42. Wu, P.; Li, F.; Zhang, J.; Yang, B.; Ji, Z.; Chen, W. Phytochemical compositions of extract from peel of hawthorn fruit, and its antioxidant capacity, cell growth inhibition, and acetylcholinesterase inhibitory activity. BMC Complement. Altern. Med. 2017, 17, 151. [CrossRef] [PubMed]

43. Liu, Y.; Xu, P.-S.; Ren, Q.; Chen, X.; Zhou, G.; Li, D.; Li, X.-M.; Xu, K.-P.; Yu, X.; Tan, G.-S. Lycodine-type alkaloids from Lycopodiastrum casuarinoides and their cholinesterase inhibitory activities. Fitoterapia 2018, 130, 203-209. [CrossRef]

44. Afzal, S.; Chaudhry, B.A.; Ahmad, A.; Uzair, M.; Afzal, K. Antioxidant, Acetylcholinesterase, Butyrylcholinesterase, and $\alpha$-glucosidase Inhibitory Activities of Corchorus depressus. Pharmacogn. Mag. 2017, 13, 647-651. [CrossRef]

45. Moon, K.; Cha, J. Enhancement of Antioxidant and Antibacterial Activities of Salvia miltiorrhiza Roots Fermented with Aspergillus oryzae. Foods 2020, 9, 34. [CrossRef] [PubMed]

46. Zhang, L.; Tu, Z.C.; Yuan, T.; Wang, H.; Xie, X.; Fu, Z.F. Antioxidants and alpha-glucosidase inhibitors from Ipomoea batatas leaves identified by bioassay-guided approach and structure-activity relationships. Food Chem. 2016, 208, 61-67. [CrossRef]

47. Zhang, L.; Tu, Z.-C.; Xie, X.; Lu, Y.; Wang, Z.-X.; Wang, H.; Sha, X.-M. Antihyperglycemic, antioxidant activities of two Acer palmatum cultivars, and identification of phenolics profile by UPLC-QTOF-MS/MS: New natural sources of functional constituents. Ind. Crop. Prod. 2016, 89, 522-532. [CrossRef]

48. Narwal, S.; Thakur, V.; Sheoran, S.; Dahiya, S.; Jaswal, S.; Gupta, R.K. Antioxidant activity and phenolic content of the Indian wheat varieties. J. Plant Biochem. Biotechnol. 2012, 23, 11-17. [CrossRef]

49. Arts, M.J.; Haenen, G.R.; Voss, H.P.; Bast, A. Antioxidant capacity of reaction products limits the applicability of the Trolox Equivalent Antioxidant Capacity (TEAC) assay. Food Chem. Toxicol. 2004, 42, 45-49. [CrossRef] [PubMed]

50. Blažević, I.; Đulović, A.; Čikeš Čulić, V.; Burčul, F.; Ljubenkov, I.; Ruščić, M.; Generalić Mekinić, I. Bunias erucago L.: Glucosinolate Profile and In Vitro Biological Potential. Molecules 2019, 24, 741. [CrossRef]

51. Huang, D.; Ou, B.; Hampsch-Woodill, M.; Flanagan, J.A.; Prior, R.L. High-throughput assay of oxygen radical absorbance capacity (ORAC) using a multichannel liquid handling system coupled with a microplate fluorescence reader in 96-well format. J. Agric. Food Chem. 2002, 50, 4437-4444. [CrossRef]

52. Liao, H.; Banbury, L. Different Proportions of Huangqi (Radix Astragali Mongolici) and Honghua (Flos Carthami) Injection on -Glucosidase and -Amylase Activities. Evid. Based Complementary Altern. Med. 2015, 2015, 785193. [CrossRef] [PubMed]

53. Ellman, G.L.; Courtney, K.D.; Andres, V., Jr.; Featherstone, R.M. A new and rapid colorimetric determination of acetylcholinesterase activity. Biochem. Pharmacol. 1961, 7, 88-95. [CrossRef]

54. Sahin, H. Honey as an apitherapic product: Its inhibitory effect on urease and xanthine oxidase. J. Enzym. Inhib. Med. Chem. 2016, 31, 490-494. [CrossRef] [PubMed]

55. Xie, X.; Tu, Z.-C.; Zhang, L.; Zhao, Y.; Wang, H.; Wang, Z.-X.; Zhang, N.-H.; Zhong, B.-Z. Antioxidant activity, $\alpha$-glucosidase inhibition, and phytochemical fingerprints of Anoectochilus roxburghii formula tea residues with HPLC-QTOF-MS/MS. J. Food Biochem. 2017, 41, e12402. [CrossRef]

56. Deng, W.; Liu, K.; Cao, S.; Sun, J.; Zhong, B.; Chun, J. Chemical Composition, Antimicrobial, Antioxidant, and Antiproliferative Properties of Grapefruit Essential Oil Prepared by Molecular Distillation. Molecules 2020, 25, 217. [CrossRef] [PubMed] 